\title{
Fadia Faqir The Cry of the Dove (2007): Identity Wandering between Tradition and Modernity
}

\author{
Wafa Kheira LASRI \\ Department of English, University of AbouBekr Belkaid \\ Tlemcen, Algeria \\ Wassila HAMZA REGUIG MOURO \\ Department of English, University of AbouBekr Belkaid \\ Tlemcen, Algeria
}

\begin{abstract}
It is widely known that Western invasion brought new ideologies over colonized countries, from eradicating its traditions to impressive news reforms. Thus, the colonized country becomes torn between former traditions and newly modern perspectives. In this respect, the focus of this research paper will fall over as it witnessed Western imposition over its society that tried, in its turn, to maintain a traditional lifestyle, while there were attempts for change. Hence, the researcher attempts to shed light on Jordan-as it sways between traditions and imposed reforms- through the literary work of Fadia Ahmed Faqir, whose main motivation resides in the strong messages she conveys in her novel The Cry of the Dove. Thus, the concern of this paper is how far carrying a double identity affects people's sense of belonging? In this respect, the article introduces a hint of the author's life embodied in the protagonist Salma, who carries a swaying identity torn between tradition and modernity through her adventures. Salma moves forward and backward through time, then she- the protagonist-wins a voice in a foreign country and adopts a new standard of living, releasing herself from the cultural boundaries of Jordan. Salma is naïve but loses her original identity while she had an opportunity to be a wife, with her husband who travels to provide for his family. But she flies to Britain rejecting the double life she leads between her traditional and modern habits. As this paper submits, the addressees should depict the impact of living a double identity adopted by a traditional character living in an imposed body and culture.
\end{abstract}

Keywords: Cultural boundaries, double identity, social change, tradition vs. modernity, Western reforms, women's oppression

Cites as: LASRI, W. K., \& MOURO, W. H. R. (2019). Fadia Faqir The Cry of the Dove (2007): Identity Wandering between Tradition and Modernity. Arab World English Journal for Translation \& Literary Studies, 3 (3) 113-122. DOI: http://dx.doi.org/10.24093/awejtls/vol3no3.8 